\title{
Effect of Temperature and Zinc on Development of Tobacco-Mosaic Virus in Resistant and Susceptible Tomatoes ${ }^{1}$
}

\author{
Justo López García ${ }^{2,3}$
}

\section{INTRODUCTION}

The tomato, Lycopersicon esculentum Mill., is one of the most popular vegetable crops in the world. In the United States it is widely cultivated, being second only to potatoes in dollar value. Because of its significance to the agricultural economy, this crop has received major attention in research. Many studies have been conducted to attain a better understanding of the relationship between nutrition of the plant and disease development. It is generally acknowledged that a well-nourished plant has better ability to resist infection by certain disease organisms than a weak, undernourished one. A well-nourished plant should be considered as one that has the essential nutrients available at the appropriate time and has the ability to use them for optimal growth.

Assuming that all the required elements are available, other environmental factors must be at an optimum if plants are to make maximum growth. Temperature is one of the most important environmental factors, affecting both the physiologic and metabolic processes of the plant. Different temperatures may alter the resistance or susceptibility of the plants to certain diseases.

Although the relationships of nutrition and temperature to plant growth, infection, and disease development have been investigated by several workers, it appeared that new studies might lead to a better understanding of certain important diseases. The virus diseases constitute one of the

1 Submitted in partial fulfilment of the requirements for the degree of Master of Science from Oregon State University, Corvallis, Oreg.

2 Assistant Agronomist, Fortuna Substation, Agricultural Experiment Station, University of Puerto Rico, Río Piedras, P.R.

3 The author wishes to express his very sincere and deep appreciation to his major professor, Dr. W. A. Frazier, for his inspiring guidance, continuous encouragement, and invaluable assistance during this study and in the preparation of this manuscript. Thanks are also expressed to his minor professor, Dr. E. K. Vaughan, for his assistance during the investigation and preparation of the present thesis; to Dr. Harry J. Mack, for his assistance with the zinc-treatment technique; to Dr. John A. Milbrath, for furnishing the strain of TMV used in this study; and to Dr. J. N. Singh, for his able assistance with the statistical analyses. And finally, but not least, sincere appreciation is also extended to his wife for her continuous encouragement and invaluable assistance. 
serious threats to our horticultural crops. It is well known that tobacco mosaic is an important economic disease of the tomato plant. Tobaccomosaic virus (TMV) is one of the most, if not the most, widely distributed viruses affecting tomato. The purpose of this study was to determine the effects of temperature and of zinc on the development of tobacco-mosaic virus (TMV) in resistant and susceptible varieties of tomato.

\section{REVIEW OF LI'TERA'TURE}

Adolf Maycr (22), ${ }^{4}$ in 1886 described a disease of the tobacco plant, Nicotiana tabacum using the term "mosaic" which is now widely used for describing the mottling type of virus discases. Iwanosky (16), in 1892 proved the filterability of infected plant sap by passing it through a bacteriaproof filter-candle. Beijerinck (5), in 1898 first used the term "virus" to describe the causative agent of tobacco mosaic. It was not until 1935 that Stanley (32) isolated the virus and described it as a glycoprotcin. The same year Bawden and Pirie reported that the virus was a nucleoprotein. Since 1935 tobacco-mosaic virus has been studied by hundreds of different investigators.

Although TMV attacks many hosts, certain members of the Solanaceae seem to be preferred. Within this family it is found commonly on tobacco, Nicotiana tabacum, L.; tomato, Lycopersicon esculentum, Mill.; and garden pepper, Capsicum frutescens, L. In most susceptible varieties of tobacco the symptoms of the disease generally are light-green spots, followed by vein-clearing, distortion, and greenish-yellow mottling of newly formed leaves. Some strains of tobacco, in which TMV infection causes necrotic lesions, have been produced in an attempt to perform better and easier assays of the virus. The tomato plant does not, as a rule, show any visible primary lesions; the systemic disease is characterized by greenish-yellow mottling of foliage, moderate distortion of leaf shape, and a reduction of fruit yield. When potato virus $\mathrm{X}$ (PXV) is also present a more severe disease known as "double virus-streak" is induced. Tobacco-mosaic virus is primarily transmitted by mechanical means although it may be transmitted, to some extent, by aphids. It also may be transmitted through the seed in tomato, but not in tobacco (13).

Numerous studies have been conducted in an attempt to clarify the role of host nutrition on TMV infection and multiplication. Bawden and Kassanis (3) reported that the number of local lesions produced in leaves of Nicotiana tabacum and Nicotiana glutinosa by tomato aucuba-mosaic virus and TMV was increased by additions of both nitrogen and phosphorus, provided these also increased growth. In other experiments, Baw-

4 Italic numbers in parentheses refer to Literature Cited, pp. 130-2. 
den and Kassanis (4) found that the concentration of virus in the sap from potato plants systemically infected with two strains of potato virus $\mathrm{X}$ was not consistently affected by fertilizers; the chief effect of host nutrition on virus reproduction was indirect, by altering plant size.

On the other hand, Weathers and Pound (89) reported that, with variations in the concentration of balanced nutrient solutions, there was a close correlation of host growth and virus concentration. The highest lesion counts and optical-density readings were obtained when both nitrogen and phosphorus were at the optimum levels for plant growth. Nitrogen and phosphorus are essential for virus synthesis and it may be expected that variations in these elements might affect virus multiplication.

Tobacco-mosaic virus appears to affect the mineral composition of the leaves of virus-infected tomato plants, for Bergman and Boyle (7) reported that TMV infection, although not significantly affecting $\mathrm{P}, \mathrm{K}, \mathrm{Ca}$, $\mathrm{Mg}$, and $\mathrm{B}$ in leaves, did affect the $\mathrm{Mn}, \mathrm{Fe}, \mathrm{Cu}, \mathrm{Al}$, and $\mathrm{Zn}$ content significantly. It is worthwhile to note that the elements that were significantly decreased were those involved in the activation of enzymes. These enzymes may be involved in virus synthesis. Micronutrients have been considered, by several workers, to play key roles in host growth and virus multiplication. According to Loring and Waritz (21) $\mathrm{Fe}, \mathrm{Cu}, \mathrm{Mg}$, and probably $\mathrm{Ca}$ are integral viral components. Similarly, Pound and Welkie (28) reported that marked deficiencies of Fe seemed to limit the effects of virus infection. This might be attributed to reduced virus multiplication in plants extremely deficient in $\mathrm{Fe}$. Since $\mathrm{Fe}$ is essential for enzyme activation it is possible that $\mathrm{Fe}$ deficiencies would reduce virus synthesis and multiplication. Tobacco plants deficient in $\mathrm{Mg}$ (32), $\mathrm{Mo}$ (25), and $\mathrm{S}$ (20) were found to have lower virus concentrations than plants having optimum levels of these elements.

On the other hand, Mn-deficient tobacco-plant tissue reached a higher level of virus concentration than normal plant tissue when samples were assayed on either a dry or a wet basis, and by either ultraviolet absorption or local lesion assays (41). Boron is probably not involved in TMV multiplication, other than indirectly by favoring a more vigorous host plant, as reported by Shepherd and Pound (31).

Zinc nutrition appears to have been studied to a great extent by several investigators. Helms and Pound (11) working with tobacco plants, found that development of virus symptoms was more pronounced in plants grown in nutrient solutions having zinc levels optimal for growth than in plants grown at deficient levels. They also reported that TMV multiplication is associated with the utilization of zinc, or with the withdrawal of the element from the leaves in which virus multiplication is occurring. Zinc seems to be essential for the general metabolic processes within the plant, 
for Skoog (33) concluded that it is required for normal auxin activity in tomato plants.

On the other hand, Weintraub et al. (40) suggested that the zinc ion was responsible for the inhibition of TMV in detached half-leaves of Nicotiana tabacum. They also suggested that the zinc ion must be in soluble form to be effective. Working with tomatoes, Smith (34) found that the higher zinc concentrations tended to increase the resistance of the plants to late blight, Phylophthora infeslans. Finally, Yarwood (42) reported that the same zinc treatments which increased the number of local lesions on beans reduced the number of local lesions on Nicotiana tabacum.

Temperature has been found to exert considerable influence upon the growth and susceptibility of the host as well as on virus multiplication. Bancroft and Pound (1) reported that, 4 days after inoculation, a sharp gradient of virus concentration existed in inoculated leaves of the susceptible variety of tobacco, the concentration increasing with increasing temperature. Similarly, in resistant tobacco varieties, the highest virus concentrations were always found in plants grown at the highest temperatures, when severe symptoms were produced (2). Vaughan (37) also found that the most rapid TMV multiplication occurred in all tests at temperatures from $25^{\circ}$ to $30^{\circ} \mathrm{C}$. On the other hand, it was reported by Ford and Ross (9), working with tobacco plants and potato virus $\mathrm{X}$ and potato virus $\mathrm{Y}$, that, in general, symptom severity increased as temperature decreased. Meanwhile, it was found in another experiment by Hildebrandt et al. (12), that local lesion production was greatest from cultures at $24^{\circ}, 26^{\circ}$, and $28^{\circ} \mathrm{C}$.; least at $36^{\circ}$ and $37^{\circ} \mathrm{C}$., and intermediate at $4^{\circ}, 8^{\circ}, 20^{\circ}$, and $42^{\circ} \mathrm{C}$.

Sometimes interaction occurs between viruses, and this interaction is affected by temperature. Murakishi (23), working on tomatoes with TMV and potato virus $\mathrm{X}$, found that at $28^{\circ} \mathrm{C}$. TMV multiplication in doubly infected susceptible plants was rapid; multiplication of potato virus was inhibited. According to Pound, the virus concentration was always higher in horseradish plants grown at $16^{\circ} \mathrm{C}$. than in those grown at $28^{\circ} \mathrm{C}$. He also suggested the possibility of an inhibitor in horseradish plants occurring in greater concentrations at one temperature than at another. Preinoculation heating of bean leaves has been found not only to increase the number of local lesions, but also to result in larger lesions (29).

Differences in photoperiods and light intensities have also been studied in tobacco plants in relation to virus multiplication. Long periods of diffuse light were found more favorable for virus multiplication than short periods of intense light (27). All the evidence indicates that both nutrition and temperature are important factors in the interaction of plant growth and virus multiplication. 
Plant breeders have conducted numerous studies of resistance to virus diseases, especially TMV. Although it was not the primary purpose of this study to deal with inheritance to TMV in tomatoes, it was deemed advisable to use susceptible and resistant types, and a brief review is therefore given here.

The wild species, Lycopersicon pimpinellifolium, $L$. peruvianum, and $L$. hirsuitum have been used as a source of resistance to TMV. Holmes (14) reported a tendency to escape TMV in derivatives from a cross between $L$. esculentum Mill, and $L$. chilense. His evidence suggests that this character is hereditary. In another experiment Holmes (15) found that, in a series of backcrosses to susceptible lines, segregation occurred in the approximate ratio of $1: 1$. He concluded that the tendency to escape infection by TMV was dependent on a single dominant gene. Watson and Heinrich (38) studied the inheritance of resistance to TMV in crosses of $L$. esculentum var. Sioux $\times L$. hirsulum. A ratio of 3 symptomless plants to 1 plant with symptoms was obtained in the backcross to $L$. hirsutum. This indicated at least two factors for symptom expression. Frazier and Dennett (10) and Kikuta and Frazier (17), working in Hawaii, used L. esculentum, $L$. hirsutum, and L. pimpinellifolium as sources of resistance to TMV. The varieties Hawaii 6832 and OSU-8 used in the experiments reported here and the materials used by Holmes in his backcross study, were derived from these interspecific crosses.

\section{MATERIALS AND METHODS}

MATERIALS

The tomato varieties used in this study were: 1 , OSU-435-4 susceptible check, developed in Oregon; 2, OSU-8 originated in Hawaii for resistance to TMV; 3, Hawaii 6832 developed in Hawaii for resistance to TMV; 4, California 62 PM 22 developed in California and reported as resistant to TMV.

\section{Varielal Background}

HAWAII 6832 -This is a derivative from a multiple cross (L. esculentum) $\times$ (L. peruvianum $\times L$. pimpinellifolium $) \times(L$. hirsutum $)$. Because of the complexity of the cross, it is difficult to predict the specific origin of its resistance; however, it is well known that there is resistance to TMV in L. peruvianum, L. pimpinellifolium, and L. hirsutum.

CALIFORNIA 62 PM 22-This variety was kindly furnished by Dr. Paul G. Smith of the University of California at Davis. This was an $F_{3}$ of the cross Pearson $\times\left(\right.$ Red Cherry $\times$ Solanum pennellii $\left.\mathrm{F}_{2}\right)$.

osu-435-4-The parentage of this variety is (Campbell Selection $10 \times$ 
Pennheart) $\times$ Queens. The original cross was made in 1949; it was next crossed to Queens in 1953. It was selected as single plants in 1957, 1958, and 1959, then massed in 1960 and subsequent years.

OSU-8 - Same parental background as Hawaii 6832.

TOBACCO VARIETY: The tobacco strain Necrotic Turk used in this study was derived from a cross of Nicotiana tabacum $\times$ Nicotiana glutinosa. It is the result of breeding work designed to secure a better test host for local lesions assays of TMV.

TMV STRAIN: The common strain of TMV was used in the present study. The strain was inoculated to a tobacco plant of the variety Samsun and this systemically infected plant was used to prepare the inoculum to inoculate the tomato plants.

zINC: Zinc sodium ethylenediamine tetracetate (E.D.T.A.), containing 14.2-percent zinc, was utilized for the foliar sprays at a rate of $1 \mathrm{gm}$./liter of water. This was a zinc concentration of about 142 p.p.m.

\section{METHODS}

\section{First Experiment}

Tobacco seed were planted in the first week of December 1962, in a 1gallon metal can. The can was filled to within 1 inch of the top with ordinary greenhouse soil and irrigated. Then the seed were spread over the soil and covered with about $1 / 4$ inch of fine sand. The can was kept under normal greenhouse conditions. Individual tobacco seedlings were transplanted February 2, 1963, to 1-gallon metal cans filled with greenhouse soil. One teaspoonful of complete fertilizer had been mixed with the soil prior to planting.

The tomato seed were planted in 1-gallon metal cans. Each variety was planted in a separate can filled with greenhouse soil to approximately 1 inch from the top. The seed were pressed into the soil surface with a piece of wood, then covered with about $1 / 4$ inch of fine sand. Enough moisture was provided for good germination and growth of the seedlings. The seed were transplanted February 12, 1963. Symptoms of damping-off were observed a week or so after sowing. Zerlate sprays were applied in an attempt to control this condition. After the zerlate treatments mild to severe stunting was noticed in the tomato seedlings. Finally, fermate sprays were used to control damping-off. On March 12, 1963, the seedlings were transplanted to 1-gallon metal cans filled with greenhouse soil to which 1 teaspoonful of complete fertilizer had been added. The fertilizer was thoroughly mixed prior to transplanting. Five seedlings were transplanted por can. Eighty plants of each variety were transplanted; there were 16 cans of each variety. 
The foliar sprays with zinc sodium E.D.T.A. were made with an atomizer about 10 days before the seedlings were inoculated with TMV. Using a solution containing $1 \mathrm{gm}$./liter of water, the seedlings were uniformly wetted to the run-off point. Forty plants of each variety were treated with zinc foliar sprays.

About 10 days after the zinc foliar sprays were applied the tomato seedlings were inoculated with the common strain of TMV. As a source of inoculum, $1 \mathrm{gm}$. of leaf tissue from a systemically infected Samsun tobacco plant was used. The tissue was ground in a mortar with pestle, and $10 \mathrm{ml}$. of 1-percent $\mathrm{K}_{2} \mathrm{HPO}_{4}$ was added as a diluent buffer solution.

The expressed sap was squeezed through cheesecloth. Two carborundumdusted leaves of each tomato plant were inoculated by rubbing with the forefinger. Forty plants of each variety were inoculated. Twenty of these had been, and 20 had not been treated with zinc.

Immediately after inoculation, the plants were divided into two lots and moved to the two temperature houses. Ten zinc-treated and TMV-inoculated plants of each variety were shifted to each temperature house. Ten zinc-treated, but noninoculated, plants of each variety were moved to the high-temperature and 10 were placed in the low-temperature house. Ten plants, without zinc treatment, but TMV-inoculated, of each variety were moved to each temperature house. Ten plants, without zinc treatment and noninoculated with TMV, of each variety were maintained in each house. Thus there were 40 plants of each variety in each house.

In the high-temperature house the temperature was kept at approximately $75^{\circ} \mathrm{F}$. during the day and $65^{\circ} \mathrm{F}$. at night. On the other hand, in the low-temperature house the temperature fluctuated with daily variations in outside temperature. Temperatures were recorded twice a day, in early morning and in midafternoon, from a thermometer located on the bench where the tomato plants were placed.

Because no symptoms appeared following the first inoculation with TMV, a second one was made about 1 week later. Twelve days after the second inoculation the virus titer was determined. One gram of TMV-infected tomato tissue was ground with a mortar and pestle with $10 \mathrm{ml}$. of 0.5 -percent $\mathrm{Na}_{2} \mathrm{HPO}_{4}$ buffer. The expressed sap was squeezed through cheesecloth and diluted to the following concentrations: $1: 10 ; 1: 100 ; 1: 1,000$; and $1: 10,000$. These dilutions were used to inoculate carborundum-dusted Necrotic Turk leaves and the number of local lesions was subsequently recorded. A concentration of 1:10 was found to be satisfactory in making the local-lesion assays in this experiment.

The next step was to make the local-lesion assays with the inoculum prepared from the tomato plants on the tobacco plants. The same procedure described above was used to prepare the inoculum. For each tomato plant 
one Necrotic Turk leaf was used. The tobacco leaf was tagged with the name of the variety, treatment, temperature, and number of the tomato plant.

The fresh weight of each tomato plant was determined by weighing the whole plant (leaves, stem, and roots). The weights in grams were recorded.

\section{Second Experiment}

For the second experiment essentially the same procedure was followed. Only three varieties of tomato were used in the second experiment. The variety OSU-8 was discarded because its apparent resistance was proved in the first experiment and one resistant type was considered sufficient.

Tobacco seed were planted in the first week of May 1963, following the same procedure used in the first experiment. The seedlings were transplanted June 20, 1963.

Tomato seed were planted June 22, 1963, following the same procedure as in the first experiment, except that the soil in the cans was wetted before spreading the seed, with a fermate solution (1 teaspoonful per gallon of water).

No damping-off was noted in the second experiment. About 2 weeks later the seedlings were transplanted to 1-gallon metal cans, following the procedure used in the first experiment; however, in this test one tomato seedling was transplanted to each can. Eighty seedlings of each variety were planted. The foliar sprays of zinc were applied 10 days before the inoculation with TMV. By this time the seedlings were about 1 month old.

The tomato plants were inoculated with the same common strain of TMV from a systemically infected Samsun tobacco plant, following essentially the same procedure as before. Forty plants of each variety were inoculated with TMV. Of these, 20 had, and 20 had not, received zinc treatments.

Immediately following inoculation the plants were divided into two lots and shifted to the two temperature houses. Exactly the same procedure used in the first experiment was followed. Thus, 40 plants of each variety were placed in each house.

In this experiment the temperature in the low-temperature house was kept at approximately $75^{\circ} \mathrm{F}$. during the day and at $65^{\circ} \mathrm{F}$. at night. The temperature in the hothouse, on the other hand, fluctuated with daily variations in outside temperature. This was the reverse of the situation in the first experiment. Temperatures were recorded in the high-temperature house in the early morning and in the midafternoon. Mean maximum, mean minimum, and mean daily temperatures were determined for both experiments.

Ten to twelve days after inoculation of the tomato seedlings the virus 
titer was determined following the procedure described previously. The concentration 1:1,000 was found to be the best for local-lesion assay in this experiment.

Once the virus titer was determined, assaying of the individual plants followed. One Necrotic Turk tobacco leaf was used for each tomato plant. The same methods of preparing the inoculum discussed before were used in this test. Each tobacco leaf was tagged with the name of the variety, treatment, temperature, and number of the tomato plant. The fresh weights in grams were recorded.

TABLE 1.-Efect of temperature and zinc on multiplication of TMV in tomato plants, measured by development of local lesions in Necrotic T'urk lobacco in experiment $1^{1}$

\begin{tabular}{|c|c|c|c|c|c|c|c|c|c|}
\hline \multirow{3}{*}{ Temperature } & \multirow{3}{*}{ Treatments } & \multicolumn{8}{|c|}{ Data for varieties indicated } \\
\hline & & \multicolumn{2}{|c|}{ OSU-435-4 } & \multicolumn{2}{|c|}{ Hawaii 6832} & \multicolumn{2}{|c|}{$\underset{\text { PM } 22}{\text { California }} 62$} & \multicolumn{2}{|c|}{ OSU-8 } \\
\hline & & Check & TMV & Check & TMV & Check & TMV & Check & TMV \\
\hline Low* & $\begin{array}{l}\text { Zinc } \\
\text { Without zinc }\end{array}$ & $\begin{array}{l}0 \\
0\end{array}$ & $\begin{array}{l}58.8 \\
47.7\end{array}$ & $\begin{array}{l}0 \\
0\end{array}$ & $\begin{array}{l}0 \\
0\end{array}$ & $\begin{array}{l}0 \\
0\end{array}$ & $\begin{array}{r}48.4 \\
9.3\end{array}$ & $\begin{array}{l}0 \\
0\end{array}$ & $\begin{array}{l}0 \\
0\end{array}$ \\
\hline High** & $\begin{array}{l}\text { Zinc } \\
\text { Without zinc }\end{array}$ & $\begin{array}{l}0 \\
0\end{array}$ & $\begin{array}{l}50.9 \\
66.8\end{array}$ & $\begin{array}{l}\mathbf{0} \\
\mathbf{0}\end{array}$ & $\begin{array}{l}\mathbf{0} \\
\mathbf{0}\end{array}$ & $\begin{array}{l}\mathbf{0} \\
\mathbf{0}\end{array}$ & $\begin{array}{l}25.5 \\
30.0\end{array}$ & $\begin{array}{l}\mathbf{0} \\
0\end{array}$ & $\begin{array}{l}0 \\
0\end{array}$ \\
\hline \multicolumn{5}{|c|}{ L.S.D for variety differences at: } & $\begin{array}{r}0.01 \\
.05\end{array}$ & \multicolumn{2}{|c|}{$\begin{array}{l}20.19 \\
15.08\end{array}$} & & \\
\hline
\end{tabular}

1 Temperature and treatment differences were not significant. Means of 10 plants: * Mean maximum: $68.5^{\circ} \mathrm{F}$, mean minimum: $63.9^{\circ} \mathrm{F},$. mean daily: $66.2^{\circ} \mathrm{F}$, , ** Mean maximum: $75^{\circ} \mathrm{F}$., mean minimum: $65^{\circ} \mathrm{F}$., mean daily: $70^{\circ} \mathrm{F}$.

\section{RESULTS}

\section{EXPERIMENT I}

\section{Local Lesions}

Table 1 shows the means of 10 plants which constituted the replications of each treatment. The statistical analysis is presented in table 2 . The data show that under low-temperature conditions zinc tended to increase the number of local lesions compared to the plants receiving no zinc treatments. On the other hand, at the high temperature, zinc treatments tended to reduce the number of local lesions. However in both cases, the differences were not statistically significant.

The tables clearly show differences due to variety. Although the varieties 
Hawaii 6832, California 62 PM 22, and OSU-8 were reported as resistant to TMV, the data show clearly an erratic behavior in resistance of the variety California 62 PM 22. Inoculum from the varieties Hawaii 6832 and OSU-8 produced no local lesions when inoculated to Necrotic Turk tobacco leaves, indicating that these varieties have a high degree of resistance under the conditions of this experiment. The variety differences were highly significant at both 1 - and 5-percent levels. Temperature differences were not significant.

TABLE 2.-Analysis of variance on the effect of temperature and zinc on multiplication of TMV in tomato plants, measured by development of local lesions in Necrotic

Turk lobacco in experiment 1

\begin{tabular}{|c|c|c|c|}
\hline Source of variation & $\begin{array}{l}\text { Degrees of } \\
\text { freedom } \\
\text { (DF) }\end{array}$ & $\begin{array}{c}\text { Mean square } \\
\text { (M.S.) }\end{array}$ & Fi \\
\hline $\begin{array}{l}\text { Replication } \\
\text { Treatment } \\
\text { Variety } \\
\text { Temperature } \\
\text { Treatment } \times \text { variety } \\
\text { Variety } \times \text { temperature } \\
\text { Treatment } \times \text { temperature } \\
\text { Treatment } \times \text { temperature } \times \text { variety } \\
\text { Error }\end{array}$ & $\begin{array}{r}9 \\
1 \\
3 \\
1 \\
3 \\
3 \\
1 \\
3 \\
116\end{array}$ & $\begin{array}{r}1,483.56 \\
555.03 \\
28,850.58 \\
50.63 \\
831.83 \\
91.69 \\
3,115.23 \\
1,153.23 \\
1,163.71\end{array}$ & $\begin{array}{c}1.2748 \\
.4769 \\
24.7969^{* *} \\
.0044 \\
.7148 \\
.0788 \\
2.6769 \\
.9909\end{array}$ \\
\hline Total & 140 & $1,748.88$ & \\
\hline
\end{tabular}

$1 * *$ Significant at 0.01 level.

\section{Fresh Weight}

Table 3 indicates the mean weights of 10 plants which constituted the replications of each treatment. The statistical analysis is presented in table 4. The fresh weights were affected by both zinc and temperature, as well as by TMV. In general, applications of zinc tended to increase fresh weights under both temperatures. The trend was somewhat greater in noninoculated plants, but the differences were not significant. In general, fresh weights were higher under low-temperature than under high-temperature conditions. The differences, however, were not significant.

Variety differences in fresh weight, although not significant, were interesting; there is the possibility that the trends would have been significant under conditions of better replication. The OSU-435-4 noninoculated plants, with and without zinc, and at both temperatures, showed higher mean values than the inoculated plants of the same variety grown under the same conditions. On the other hand, Hawaii 6832 inoculated plants, 
with and without zinc and at both temperatures had higher mean values than the plants without zinc grown under similar conditions.

The variety OSU-8, although it is resistant, behaved similarly to OSU-

TABLE 3.-Effect of temperalure and zinc on the fresh weight (grams) in TMV-inoculated and noninoculated resistant and susceptible tomatoes in experiment $1^{1}$

\begin{tabular}{|c|c|c|c|c|c|c|c|c|c|}
\hline \multirow{3}{*}{ Temperature } & \multirow{3}{*}{ Treatments } & \multicolumn{8}{|c|}{ Data for varieties indicated } \\
\hline & & \multicolumn{2}{|c|}{ OSU-435-4 } & \multicolumn{2}{|c|}{ Hawaii 6832} & \multicolumn{2}{|c|}{ California 62 PM 22} & \multicolumn{2}{|c|}{ OSU-8 } \\
\hline & & Check & TMV & Check & TMV & Check & TMV & Check & TMV \\
\hline \multirow[t]{2}{*}{ Low } & Zinc & 43.50 & 32.63 & 33.48 & 39.90 & 34.57 & 29.14 & 47.12 & 29.47 \\
\hline & $\begin{array}{l}\text { Without } \\
\text { zinc }\end{array}$ & 40.71 & 35.01 & 37.05 & 46.30 & 33.31 & 33.10 & 45.03 & 31.69 \\
\hline \multirow[t]{2}{*}{ High } & Zinc & 32.10 & 26.24 & 34.89 & 35.27 & 37.38 & 38.55 & 44.99 & 28.66 \\
\hline & $\begin{array}{l}\text { Without } \\
\text { zinc }\end{array}$ & 32.06 & 25.72 & 39.51 & 44.23 & 25.99 & 27.78 & 34.99 & 34.40 \\
\hline
\end{tabular}

1 Variety differences, temperature differences, and treatment differences were not significant; means of 10 plants.

TABLE 4.-Analysis of variance on the effects of tobacco-mosaic virus, zinc, and temperature on the fresh weight of the resistant and susceptible tomatoes in experiment 1

\begin{tabular}{|c|c|c|c|}
\hline Source of variation & $\begin{array}{l}\text { Degrees of } \\
\text { freedom } \\
\text { (DF) }\end{array}$ & $\begin{array}{l}\text { Mean square } \\
\text { (D.S.) }\end{array}$ & F \\
\hline $\begin{array}{l}\text { Replication } \\
\text { Treatments } \\
\text { Varieties } \\
\text { Temperature } \\
\text { Treatment } \times \text { variety } \\
\text { Variety } \times \text { temperature } \\
\text { Treatment } \times \text { temperature } \\
\text { Treatment } \times \text { variety } \times \text { temperature } \\
\text { Error }\end{array}$ & $\begin{array}{r}9 \\
3 \\
3 \\
1 \\
9 \\
3 \\
3 \\
9 \\
249\end{array}$ & $\begin{array}{r}1,263.11 \\
506.13 \\
709.55 \\
757.99 \\
528.85 \\
326.62 \\
98.29 \\
139.33 \\
565.68\end{array}$ & $\begin{array}{r}2.2329 \\
.8947 \\
1.2543 \\
1.3399 \\
.9349 \\
.5774 \\
.1737 \\
.2463\end{array}$ \\
\hline Total & 289 & 56.718 & \\
\hline
\end{tabular}

435-4, since inoculated plants with and without zinc had lower mean values for fresh weight under both temperatures than noninoculated plants. The variety California 62 PM 22 again showed very erratic behavior. Under low temperature the noninoculated plants, with or without zinc, had ligher mean values for fresh weight than inoculated plants, 
but under high temperatures the reverse occurred. Herc the inoculated plants with or without zinc showed higher mean values than noninoculated plants.

\section{EXPERIMENT 2}

\section{Local Lesions}

Table 5 shows the means of 10 plants for each treatment. The statistical analysis is presented in table 6 .

TABLE 5.-Effect of temperature and zinc on multiplication of TMV in tomato plants, measured by development of local lesions in Necrotic Turk tobacco in experiment $2^{1}$

\begin{tabular}{|c|c|c|c|c|c|c|c|}
\hline \multirow{3}{*}{ Temperature } & \multirow{3}{*}{ Treatments } & \multicolumn{6}{|c|}{ Data for varieties indicated } \\
\hline & & \multicolumn{2}{|c|}{ OSU-435-4 } & \multicolumn{2}{|c|}{ Hawaï 6832} & \multicolumn{2}{|c|}{ California 62 PM 22} \\
\hline & & Check & TMV & Check & TMV & Check & TMV \\
\hline Low* & $\begin{array}{l}\text { Zinc } \\
\text { Without zinc }\end{array}$ & $\begin{array}{l}\mathbf{0} \\
\mathbf{0}\end{array}$ & $\begin{array}{l}168.6 \\
149.4\end{array}$ & $\begin{array}{l}0 \\
0\end{array}$ & $\begin{array}{l}6.7 \\
2.3\end{array}$ & $\begin{array}{l}0 \\
0\end{array}$ & $\begin{array}{r}107.8 \\
15.1\end{array}$ \\
\hline High $^{* *}$ & $\begin{array}{l}\text { Zinc } \\
\text { Without zinc }\end{array}$ & $\begin{array}{l}0 \\
0\end{array}$ & $\begin{array}{l}268.8 \\
124.0\end{array}$ & $\begin{array}{l}0 \\
0\end{array}$ & $\begin{array}{l}\mathbf{0} \\
\mathbf{0}\end{array}$ & $\begin{array}{l}0 \\
0\end{array}$ & $\begin{array}{l}92.6 \\
67.3\end{array}$ \\
\hline D. 10 & MEDC & & & $\begin{array}{r}0.01 \\
.05\end{array}$ & $\begin{array}{l}47.4 \\
35.6\end{array}$ & & \\
\hline
\end{tabular}

1 Temperature differences were not significant, treatment differences were not significant. Means of 10 plants: ${ }^{*}$ Mean maximum: $75^{\circ} \mathrm{F}$; mean minimum: $65^{\circ} \mathrm{F}$; mean daily: $70^{\circ} \mathrm{F}$. ${ }^{* *}$ Mean maximum: $81.1^{\circ} \mathrm{F}$; mean minimum: $61.7^{\circ} \mathrm{F}$; mean daily: $71.1^{\circ} \mathrm{F}$.

Analysis of variance shows that treatments with zinc resulted in consistent, but not significant, increases in number of local lesions produced by inoculum from plants grown under both temperatures. One exception was the Hawaii 6832 line in which no local lesions were produced by inoculum prepared from plants grown at high temperature.

Variety differences for local lesions were highly significant. Because of the extremely erratic behavior for resistance to TMV, the variety California 62 PM 22 was omitted from the statistical analysis of variance. Individual plants obviously varied genetically for resistance and this source of error was thereby removed. Although Hawaii 6832 normally is highly resistant, in this experiment the inoculum prepared from this variety, with and without zinc, produced some local lesions when plants 
were grown under the low temperature, but none when they were grown under the high-temperature conditions.

\section{Fresh Weight}

The statistical analysis of variance for fresh weights is presented in tables 7 and 8. In general, low-temperature conditions increased the freshweight means significantly at the 1 - and 5 -percent levels. Zinc treatments increased the fresh-weight means, but differences were not significant.

The data show highly significant differences for the varieties at the 1and 5-percent levels. The variety OSU-435-4 had higher fresh weights in

TABLE 6.-Analysis of variance on the effect of temperature and zinc on multiplication of TMV in tomato plants, measured by development of local lesions in Necrotic Turk tobacco in experiment 2

\begin{tabular}{|c|c|c|c|}
\hline Source of variation & $\begin{array}{c}\text { Degrees of } \\
\text { freedom } \\
\text { (DF) }\end{array}$ & $\begin{array}{l}\text { Mean square } \\
\text { (M.S.) }\end{array}$ & Fi \\
\hline Replication & 9 & $3,649.52$ & 0.5740 \\
\hline Treatment & 1 & $21,125.00$ & 3.3226 \\
\hline Variety & 1 & $615,654.05$ & $96.8326^{* *}$ \\
\hline Temperature & 1 & $5,412.05$ & .8512 \\
\hline Treatment $X$ variety & 1 & $18,361.80$ & 2.8880 \\
\hline Variety $\times$ temperature & 1 & $8,778.05$ & 1.3806 \\
\hline Treatment $\times$ temperature & 1 & $31,840.20$ & $5.0079^{*}$ \\
\hline Treatment $\times$ temperature $\times$ variety & 1 & $35,448.20$ & 5.5754 \\
\hline Error & 63 & $6,357.92$ & \\
\hline Total & 79 & $14,810.30$ & \\
\hline
\end{tabular}

$1 *$ Significant at 0.05 level, ** significant at 0.01 level.

the noninoculated plants, with and without zinc, than in the inoculated plants, with the exception of the zinc-treated plants at the low temperature. The California 62 PM 22 zinc-treated and TMV-inoculated plants under high temperature had greater mean values than the noninoculated plants with zinc; however, under low temperature the reverse occurred. In general, the fresh weights of the Hawaii 6832 line were somewhat similar in all treatments and temperatures. But under the low temperature the zinctreated plants, inoculated and noninoculated, had greater fresh weights than the plants without zinc, inoculated and noninoculated, under the same temperature.

The greatest differences appeared to be between the California 62 PM 22 and the other two lines. The fresh weights of this variety were consistently lower than those of the varieties Hawaii 6832 and OSU-435-4. The 
TaBLE 7.-Effects of temperature and zinc on fresh weight of TMV-inoculated and noninoculated resistant and susceptible tomatoes, in experiment 2 (weights in grams) ${ }^{1}$

\begin{tabular}{|c|c|c|c|c|c|c|c|}
\hline \multirow{3}{*}{ Temperature } & \multirow{3}{*}{ Treatments ${ }^{2}$} & \multicolumn{6}{|c|}{ Data for varieties indicated } \\
\hline & & \multicolumn{2}{|c|}{ OSU-435-4 } & \multicolumn{2}{|c|}{ Hawaii 6832} & \multicolumn{2}{|c|}{ Californja 62 PM 22} \\
\hline & & Check & TMV & Check & TMV & Check & TMV \\
\hline \multirow[t]{2}{*}{ Low } & Zine & 194.93 & 200.12 & 180.54 & 176.53 & 153.68 & 141.84 \\
\hline & Without zinc & 198.52 & 175.75 & 180.44 & 175.04 & 156.57 & 164.44 \\
\hline \multirow[t]{2}{*}{ High } & Zinc & 184.47 & 167.33 & 170.50 & 175.52 & 150.06 & 154.73 \\
\hline & Without zinc & 187.75 & 168.90 & 183.48 & 181.44 & 137.63 & 125.53 \\
\hline
\end{tabular}

L.S.D. for variety differences at:

0.01

8.08

.05

6.12

L.S.D. for temperature differences:

$.01 \quad 16.19$

$05 \quad 12.27$

1 Means of 10 plants.

2 Treatment differences were not significant.

TABLE 8.-Analysis of variance on the effects of tobacco-mosaic virus, zinc, and temperature on the fresh weight of resistant and susceptible tomaloes in experiment 2

\begin{tabular}{l|r|r|c}
\hline \multicolumn{1}{c|}{ Source of variation } & $\begin{array}{r}\text { Degrees of } \\
\text { freedom } \\
\text { (DF) }\end{array}$ & $\begin{array}{r}\text { Mean square } \\
\text { (M.S.) }\end{array}$ & Fs \\
\hline Replication & 9 & 787.56 & $2.0301^{*}$ \\
Treatments & 3 & 910.02 & 2.3457 \\
Varieties & 2 & $30,428.99$ & 78.4373 \\
Temperature & 1 & $5,142.08$ & $13.2548^{* *}$ \\
Treatment $\times$ variety & 6 & 548.20 & 1.4131 \\
Variety $\times$ temperature & 2 & $1,223.13$ & 3.1528 \\
Treatment X temperature & 3 & 108.61 & .2799 \\
Treatment $\times$ variety $\times$ temperature & 6 & $1,639.91$ & $4.2272^{* *}$ \\
Error & 207 & 387.94 & \\
\hline \multicolumn{1}{c}{ Total } & 239 & 791.76 & \\
\hline
\end{tabular}

1 * Significant at 0.05 level; ** Significant at 0.01 level.

differences between these latter two varieties were not significant; but the variety (OSU-435-4 generally had higher mean values than Hawaii 6832.

\section{DISCUSSION}

The data presented indicate that, in general, high temperature increased the development of TMV in the tomato plants, as shown by the increased 
number of local lesions produced on Necrotic Turk tobacco plants. In both experiments, however, the differences were not significant. In the first experiment a 1:10 dilution was shown to be appropriate for locallesion assays; in the second experiment the virus concentration was higher and it was necessary to use a dilution of 1:1,000.

The first experiment was run in the late winter and carly spring when short, cool, and cloudy days prevailed; the second test was run in late spring and summer when days were longer, rather sunny, and warmer. It seems likely that these environmental factors affected virus concentration and multiplication. Vaughan (87) reported that the most rapid multiplication of TMV occurred at temperatures of $25^{\circ}$ and $30^{\circ} \mathrm{C}$. Similarly, Bancroft and Pound $(1,2)$ found that virus concentration increased with increase in temperature. Pound and Bancroft (27) showed that photoperiods of 12 and 16 hours increased concentration of TMV in inoculated tobacco plants.

They also found that, in general, high light intensity favored virus multiplication. In the present experiments increased temperature and day-length tended to increase the virus concentration and multiplication. Temperature and photoperiod affect the rate of growth as well as the general physiologic and metabolic processes of the host plant. As the temperature is increased, within limits, with an increase in day-length, the rate of growth is favored and, indirectly, virus multiplication may be increased. Bawden and Kassanis $(3,4)$ in two experiments reported that virus multiplication was correlated with host-plant growth.

Fresh weights were increased slightly with increased temperature in the first experiment; however, the differences were not significant. On the other hand, in the second experiment the trend was towards increased fresh weight under low temperature and the differences were significant. It seems that the tomato plants grow better at temperatures from $65^{\circ}$ to $75^{\circ} \mathrm{F}$. rather than at lower or higher temperatures. It is interesting to note that the temperature in the high-temperature house in the first experiment was the same as that for the low-temperature house of the second experiment.

Zinc increased virus concentration under low temperature in the first experiment, and under both high and low temperatures in the second. These findings are in accordance with those of Helms and Pound (11) who found that the virus concentrations increased with increasing levels of zinc up to the optimum level for growth. Zine is well known as one of the essential elements for enzyme activation.

Thus it may be that this element plays an important role in the enzymatic system responsible for virus synthesis and multiplication. In the first experiment zinc increased the fresh weights of the rarieties OSU-435-4, 
California 62 PM 22, and OSU-8, when applied to noninoculated plants under both temperatures, but the zinc-treated and TMV-inoculated plants of the same varieties showed a decrease in fresh weights. These differences, however, were not significant.

In the second experiment zinc-treated plants showed some differences in fresh weights as compared with the plants without zinc; however, the differences were not significant. The variety OSU-435-4 plants when zinctreated, and TMV-inoculated under low temperature, had greater fresh weights than the noninoculated plants, whereas similarly treated plants of the same variety under high temperature had lower fresh weights than the noninoculated plants. The opposite occurred in the California 62 PM 22 line. The zinc-treated and TMV-inoculated plants under the low temperature had lower fresh weights than the noninoculated plants, but under the high temperature similarly treated plants of the same line had greater fresh weights. With the Hawaii 6832 line at low temperature, both with and without zinc, the noninoculated plants had greater fresh weights than the inoculated plants similarly treated.

Under high-temperature conditions without zinc, inoculated and noninoculated plants had greater fresh weights than zinc-treated plants. These results indicate that zinc effects vary with temperature, but especially with the varieties, as would be expected. The general trend, however, was towards a decrease in fresh weight with TMV-inoculated plants. Apparently either zinc is utilized in the virus synthesis, or its effects on plant growth are inhibited by the impact of the virus.

The data show variety differences in local lesions in both experiments. Of the varieties used in the first experiment, three were reported as resistant and one susceptible to TMV. However, in the first experiment a high degrse of heterozygosity for resistance of the line California 62 PM 22 was notj ed. This breeding line is thus highly heterozygous for resistance to the $c$ nmon strain of TMV. Some plants displayed a very high degree of resis nce, others were intermediate, and still others were highly susceptibl. .

The number of local lesions produced on inoculated tobacco leaves by inoculum prepared from TMV-infected plants of this variety was used as the criterion. The variety OSU-435-4 behaved as expected, indicating its susceptibility by the high number of local lesions produced on tobacco leaves by inoculum prepared from TMV-infected plants of this variety. Inoculum prepared from TMV-infected plants of the varieties Hawaii 6832 and OSU-8 produced no lesions in inoculated tobacco leaves, indicating their high degree of resistance to the common strain of TMV under the conditions of this study.

In the second experiment the varieties behaved much the same as in the 
first. Inoculum prepared from TMV-infected Hawaii 6832 plants produced local lesions in tobacco leaves in this test, but they were reduced in number as compared with the other two varieties. It is interesting to note that the inoculum was prepared from Hawaii 6832 plants grown under low-temperature conditions under which, in general, better growth took place. These findings coincide with studies conducted with tobacco plants by different workers $(3,4,31)$.

In the first experiment differences for fresh weight between varieties existed, but they were not significant; however, in the second experiment the differences were highly significant. It is worthwhile to note that in the first test five plants were grown per can whereas in the second individual plants grew in each can. There was competition for food, air, and light in the first experiment which affected the general growth of the plants. Besides, the first experiment was run in late winter and early spring with rather cool, cloudy, and short days whereas the second test was run in late spring and summer with rather longer, sunny, and warmer days more favorable for general growth.

\section{CONCLUSIONS}

The effects of temperature and zinc on development of TMV in resistant and susceptible varieties of tomato were studied in two experiments conducted under greenhouse conditions. The data of this study show that:

1. Increase in temperature tended to increase virus multiplication.

2. Zinc applied as foliar sprays appeared to be involved in virus synthesis and multiplication, with higher virus concentrations associated with addition of zinc.

3. The varieties Hawaii 6832 and OSU-8 were highly resistant; the variety California 62 PM 22 was heterozygous for resistance; and the variety OSU-435-4 was highly susceptible to the common strain of TMV under the conditions of these experiments.

\section{SUMMARY}

An investigation of the effects of temperature and of zine on the development of tobacco-mosaic virus (TMV) in resistant and susceptible varieties of tomatoes was conducted under greenhouse conditions. The study included two experiments, one run during late winter and early spring, and the other during late spring and summer, 1963. Each experiment comprised four treatments and two temperatures.

The tomato lines Hawaii 6832, OSU-8, and California 62 PM 22 were used as resistant varieties, whereas the OSU-435-4 line was used as the susceptible one.

The common strain of tobacco-mosaic virus was used in this study. 
Zinc foliar sprays were applied to the tomato plants about 10 days before the seedlings were inoculated with TMV. Immediately after inoculation the plants were divided into two lots and moved to the two temperature houses (cool and hot).

The virus concentration was determined by the local lesion assay. One gram of leaf tissue from the tomato plants was ground in a mortar with pestle and a $10-\mathrm{ml}$. buffer solution added. The extracted sap was squeezed through cheesecloth. One carborundum-dusted leaf of Necrotic Turk tobacco was inoculated. The local lesions were subsequently counted and used as a criterium.

Increase in temperature tended to increase virus concentration, although the differences were not significant. Fresh weights of the tomato plants were found to be greater at lower temperatures.

Zine foliar sprays resulted in higher virus concentration and in production of an increased number of local lesions when the inoculum prepared from such treated plants was rubbed into Necrotic Turk tobacco leaves. Effects of zinc on fresh weights were not statistically significant. Zinc applied as foliar sprays appeared to be involved in virus synthesis and multiplication, with higher virus concentrations associated with the addition of zinc.

The varieties Hawaii 6832 and OSU-8 were highly resistant, the variety California 62 PM 22 was heterozygous for resistance, and the variety OSU435-4 was highly susceptible to the common strain of TMV under the conditions prevailing in these experiments.

\section{RESUMEN}

Se estudiaron los efectos de la temperatura y del zinc sobre el desarrollo del virus del mosaico del tabaco en variedades de tomates, tres resistentes y una susceptible, en experimentos llevados a cabo en un invernadero. El estudio consistió de dos experimentos, uno hecho a fines del invierno y principios de la primavera, y el otro a fines de la primavera y durante el verano de 1963. Cada experimento comprendió cuatro tratamientos y dos temperaturas distintas.

Se usaron la Hawaii 6832, OSU-8 y California 62 PM 22 como variedades resistentes, y la OSU-435-4 como variedad susceptible.

En el estudio se usó la cepa corriente del virus del mosaico del tabaco.

Se aplicaron aspersiones foliares de zinc a las plantas de tomate alrededor de 10 días antes de que se inocularan con el virus del mosaico del tabaco. Inmediatamente después de la inoculación se dividieron las plantas en dos grupos y se mantuvieron almacenadas a dos diferentes temperaturas (alta y baja).

Se determinó la concentración del virus por el método de lesiones localizadas. Se maceró en un mortero $1 \mathrm{gm}$. del tejido de las plantas de tomate, 
añadiéndosele $10 \mathrm{ml}$. de una solución neutralizadora. El extracto se pasó por un pedazo de estopilla. Se inoculó una hoja de tabaco de la variedad Necrotic Turk de cada planta después de cubrirse con carborundum. Se contó luego el número de lesiones localizadas, para servir de norma comparativa.

Un aumento de la temperatura hizo aumentar la concentración del virus, aunque las diferencias no fueron significativas estadísticamente. Las plantas verdes de tomate pesaron más cuando las temperaturas fueron más bajas.

Las aspersiones foliares con zinc causaron que el virus se concentrara más y se produjera un mayor número de lesiones localizadas, cuando se frotaron las hojas de la variedad Necrotic Turk con el extracto infectado. El zinc aplicado en aspersiones foliares afectó aparentemente la síntesis y la multiplicación del virus, causando concentraciones mayores del virus al añadírseles más zinc.

Las variedades Hawaii 6832 y OSU-8 fueron altamente resistentes; la California 62 PM 22 resultó heterocigótica; y la OSU-435-4 demostró ser altamente susceptible a la cepa corriente del virus del mosaico del tabaco, bajo las condiciones que prevalecieron durante estos experimentos.

\section{LITERATURE CITED}

1. Bancroft, J. B., and Pound, G. S., Effect of air temperature on multiplication of tobacco mosaic virus in tobacco, Phytopath 44: 481-2, 1954.

2. - and - Cumulative concentrations of tobacco mosaic virus in tobacco and tomato at different temperatures, Virology $2: 29-43,1956$.

3. Bawden, F. C., and Kassanis, B., Some effects of host nutrition on the susceptibility of plants to infection by certain viruses, Ann. Appl. Biol. $37: 46-57,1950$.

4. - and - Some effects of host nutrition on the multiplication of plant viruses, Ann. Appl. Biol. 87: 215-28, 1950.

5. Beijerinck, M. W., Ueber ein contagium virum fluidum als ursache der Flechenkrankheit der Tabaksblïtter, Verhandelingen der Koninklyke akademie van Wettenschappen te Amsterdam, 65(2): 3-21, 1899.

6. Bennett, C. W., Relation of food translocation to movement of tobacco mosaic, J. Agr. Res. 60: 361-90, 1940.

7. Bergman, E. L., and Boyle, J. S., Effect of tobacco mosaic virus on mineral content of tomato leaves, Phytopath 52: 956-7, 1962.

8. Cartwright, T. E., and Gauffer, M. A., Some kinetic studies on the reaction of tobacco mosaic virus with formaldehyde, Phytopath 44: 484, 1954.

9. Ford, R. E., and Ross, A. F., Effect of temperature on the interaction of potato viruses $\mathrm{X}$ and $\mathrm{Y}$ in inoculated tobacco leaves, Phytopath 52: 71-7, 1962.

10. Frazier, W. A., and Dennett, R. K., Tomato lines of Lycopersicon esculentum type resistant to tobacco mosaic virus, Proc. Amer. Soc. Hort. Sci. 54: 265-71, 1949.

11. Helms, K., and Pound, G. S., Zine nutrition of Nicotiana-labacum in relation to multiplication of tobaceo mosaic virus, Virolog! 1: 408-23, 1955.

12. Hildebrant, A. C., Riker, A. J., and Watertor, .J. I., Virus infectivity host 
tissue growth on synthetic media at different temperature and acidities, Phylopath 44: 492, 1954.

13. Holmes, F. O., The filterable viruses., Sup. No. 2 Bergey's Manual of Determinative Bacteriology, 6th ed., pp. 1164-66, 1948.

14. - - A tendency to escape tomato mosaic virus disease in derivatives from a hybrid tomato, Phylopath 9s: 391-7, 1943.

15. - Inheritance of resistance to tobacco mosaic virus in tomato, Phytopath 42: $467,1952$.

16. Iwanowski, D., Ueber die Mosaikkrankheit der Tabakspflanze, St. Petersburg Acad. Imper. Sci. B. 35, 67-70, Sept. 1892.

17. Kikuta, K. and Frazier, W. A., Preliminary report on breeding tomatoes for resistance to tobacco mosaic virus, Proc. Amer. Soc. Hort. Sci. 49: 256-61, 1947.

18. Lingle, J. C., Holmberg, D. M., and Zobel, M. P., Zine deficiency of tomatoes. California Report of Progress in Research, Calif. Agr. Expt. Sta. $11(9)$ : 10, Sept. 1957.

19. - - - and - The correction of zinc deficiency of tomatoes in California, Proc. Amer. Soc. Hort. Sci., 72: 397-402, 1958.

20. LiNk, K. C., AND Pound, G. S., Sulfur nutrition of Nicotiana labacum in relation to multiplication of tobacco mosaic virus, Phylopalh 52: 155-8, 1962.

21. Loring, H. S., and Waritz, R. S., Occurrence of iron, copper, calcium, and magnesium in tobacco mosaic virus, Sci. 25: 646-8, 1957.

22. Mayer, A., Ueber die Mosaikkrankheit des Tabaks, Die landwirtschaftlichen Versuchs-Stationen 38: 451-76, 1886.

23. Murakishi, H. H., Virus multiplication and the synergistic response in tomato as modified by host resistance and temperature, Phytopath 52: 22, 1962.

24. Nichols, C. W., and Pound, G. S., The retarding effect of certain hormones on tobacco mosaic symptoms, Phytopath 42: 579-80, 1952.

25. Pirone, T. P., and Pound, G. S., Molybdenum nutrition of Nicotiana tabacum in relation to multiplication of tobacco mosaic virus, Phylopath 52: 822-7, 1962.

26. Pound, G. S., The effect of air temperature on virus concentration and leaf morphology of mosaic-infected horse radish, J. Agr. Res. 78: 161-70, 1949.

27. Pound, G. S., and Bancroft, J. B., Cumulative concentrations of tobacco mosaic virus at different photoperiods and light intensities, Virology 2: 44-56, 1956.

28. Pound, G. S., and Welkie, G. W., Iron nutrition of Nicotiana tabacum L. in relation to multiplication of tobacco mosaic virus, Virology $5: 371-81,1958$.

29. Resconovitch, E. C., Heat-induced susceptibility to tobacco mosaic virus and thermal injury in bean, Virology 1s: 338-47, 1961.

30. Samuel, G., Some experiments on inoculation methods with plant viruses and local lesions, Ann. Appl. Biol. 18: 494-507, 1931.

31. Shepherd, R. J., and Pound, G. S., Influence of boron nutrition on Nicotiana tabacum on the multiplication of tobacco mosaic virus, Phytopath 50: 26-30, 1960.

32. Shepherd, R. J., and Pound, G. S., Magnesium nutrition of Nicotiana tabacum in relation to multiplication of tobacco mosaic virus, Phylopalh 50: 195-8, 1960.

33. Skoog, F., Relations between zinc and auxin in the growth of higher plants, Amer. J. Bot. 27: 939-51, 1940.

34. Smith, C. B., The nutrient-element balance of the tomato and its susceptibility to Phylophthora infestans as affected by two levels of zinc, Plant Physiol. 26: 737-49, 1951.

35. Smith, K. M., Plant Viruses, Methuen's Monographs on Biological Subjects, 3d 
ed., 1960. pp. 4-5, 19-24, 95-96, 98-100, 127-29, and 150-53, John Wiley \& Sons, Inc. New York, N. Y., 1960.

36. Spencer, E. L., The effects of host nutrition in concentration of tobacco mosaic virus, Plant Physiol. 14: 769-82, 1937.

37. Vaughan, E. K., The influence of temperature on multiplication of tobacco mosaic virus, Mededelingen Van De Landbouwhogeschool En De Opzoekingsstations Van De Staat Te Gent, Deel 20(3): 389-98, 1955.

38. Watson, R. D., and Heinrich, E. E., The inheritance to tobacco mosaic virus in interspecific tomato crosses, Phylopath. 44: 944, 1951.

39. Weathers, L. G., and Pound, G. S., Host nutrition in relation to multiplication of tobacco mosaic virus in tobacco, Phylopath. 44: 74-80, 1954.

40. Weintraub, M., Gilpatrick, J. D., and Willison, R. S., The effect of certain watersoluble compounds in virus infection, Phylopath 42: 417, 1952.

41. Welkie, G. W., and Pound, G. S., Manganese nutrition of Nicotiana tabacum in relation to multiplication of tobacco mosaic virus, Virology 5: 92-109, 1958.

42. Yarwood, C. E., Zinc increases susceptibility of bean leaves to tobacco mosaic virus. Phytopath 44: 230-3, 1954. 